\title{
On the issue of the application of wireless decisions and technologies in the digital oil and gas production
}

\author{
A.N. Dmitrievsky ${ }^{1}$, N.A. Eremin ${ }^{1 *}$, V.E. Stolyarov ${ }^{1,2}$ \\ 1 - Oil and Gas Research Institute, Russian Academy of Sciences, Moscow; \\ 2 - PJSC «GAZPROM», Moscow \\ E-mail: *ermn@mail.ru
}

Abstract. The use of remote control of field facilities and wells in oil and gas production has historically been preceded by the development of automatic and automated drilling technologies, the creation of integrated models of an efficient production, and the development of undersurface and surface parts of fields on the basis of the energy-dependent solution. There is no doubt that there is a direct link between automated (digital) wells and digital (intellectual) fields. The experience has shown that until the mid-60s, automatic devices were practically not used in domestic fields and only in the last decade this process has accelerated due to the large number of fields at the stage of declining production.

Keywords: digital oil and gas production, wireless solutions, wireless technologies, oil, gas, production, energy efficiency, mechanized production, maintaining reservoir pressure, decision-making scheme.

Citation: Dmitrievsky A.N., Eremin N.A., Stolyarov V.E. On the issue of the application of wireless decisions and technologies in the digital oil and gas production // Actual Problems of Oil and Gas. 2019. Iss. 2(25). https://doi.org/10.29222/ipng.2078-5712.2019-25.art11

On June 7, a seminar «Energy Efficient Extraction and Refining of Oil - 2019» was held in Moscow, organized by the Expert Council on Mechanized Oil Production and the National Oil and Gas Forum with the official support of the Ministry of Energy of the Russian Federation. The seminar analyzed the results of the implementation in the oil companies of the Program on improving the energy efficiency of oil and gas production, transportation and oil treatment, and the reservoir pressure maintenance systems. As a part of the discussion on the formation of criteria and methodologies for assessing the energy efficiency of the oil and gas production and refining, the practice of their application, a report by N. Eremin and V. Stolyarov «The use of wireless solutions and technologies in digital oil and gas production» was submitted and heard.

Analysis of the developed solutions for telemechanization and telemetry of wells allows us to form an optimal algorithm for selecting a typical solution, to develop a system of classification of wells and gas collection network of fields based on artificial intelligence methods. Decision-making scheme (typical algorithm) is shown in the diagram (fig. 1). 


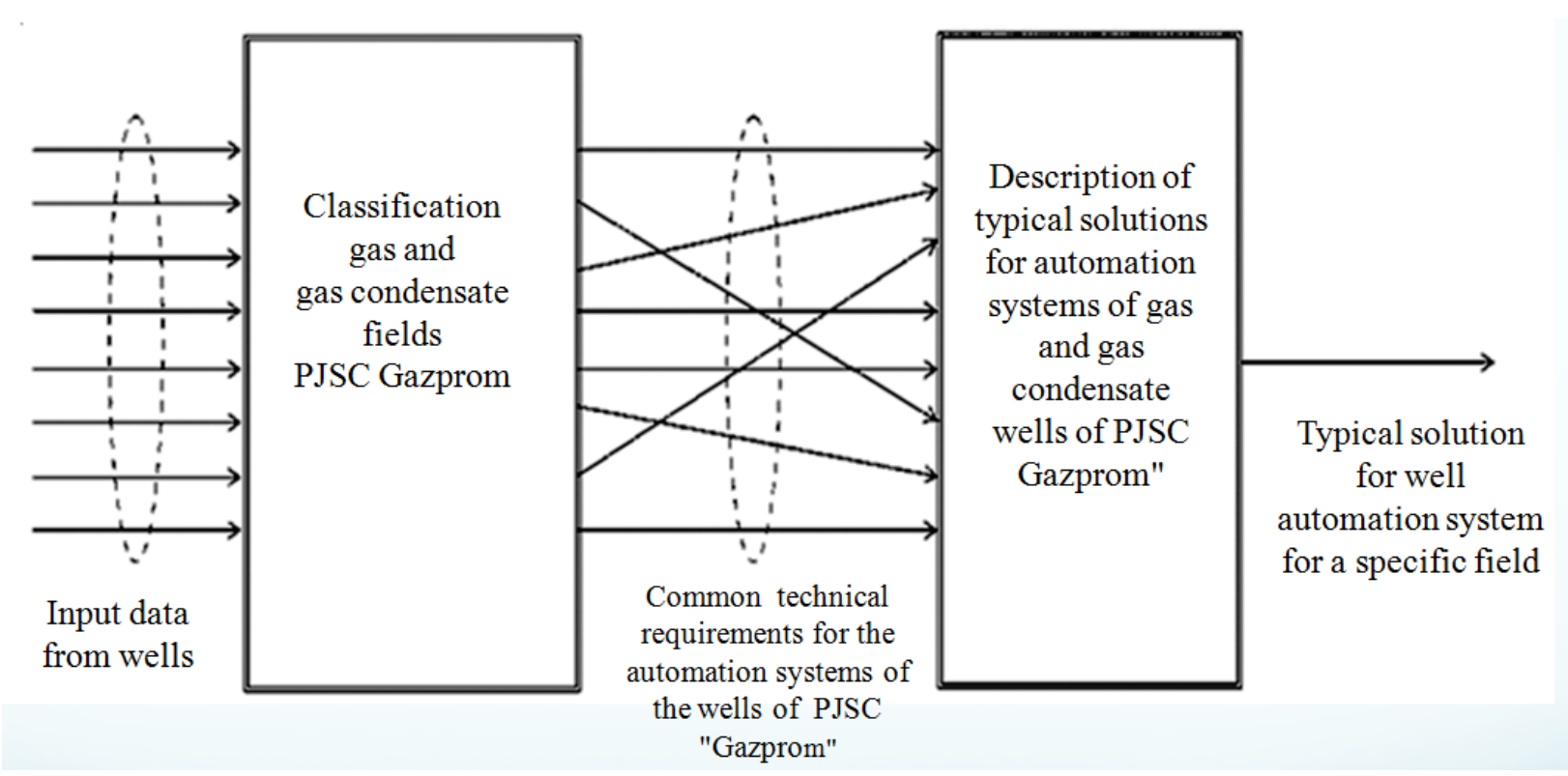

Fig. 1. The decision tree (the typical algorithm)

Classification of wells and decision-making on the volume of automation is carried out according to the algorithm, taking into account the «integrated approach» in the development of the field and the presence of a number of limiting factors and conditions, the existing functional tasks and limitations, including: design and technological features of wells, the technological scheme of prefabricated networks, the organization of Big Geo data transfer schemes, the type of production, values of well flow rates; the stage of investment and the possibility of improvement; the presence of hydrogen sulfide in the production and other restrictions on performance; climatic region of the location of fields and others [1].

A comparison of expenditures for the development with the use of energy independent solutions and standard approaches shows the possibility to provide savings in the order of $60 \%$ of the amount of initial capital investments and to reduce the time needed to automate facilities. This is achieved by saving costs for survey work, permits for land acquisition, design, construction and installation work due to the lack of communications and power supply, operational and transportation costs, to ensure planned preventive work. The experience of using similar systems in the fields confirmed that the use of wireless technologies in the technological complex of «Reservoir-Gas collection network - Gas treatment unit» makes it possible to organize the situational management of the well stock in a short time and with significant limitation of funding $[1,2]$. 
The advantage of an energy-independent solution is the possibility of implementing the basic functions of well control and management without external power supply based on the use of renewable energy sources - solar and wind generation, thermal generators, as well as permanent power sources based on diesel sources and electric generators, isotope sources and batteries. It is possible to use other sources based on renewable and non-traditional sources of electricity. Part of the implemented functions for energy supply is related to energy consumption for heating equipment, the management of fountain and power valves, providing electrochemical protection, ensuring the operability of leak detection systems and the organization of communication channels, and equipment diagnostics.

The remote-control technology allows to provide operational dynamic optimization and improvement of the quality of the production process control through the algorithmic formation of control actions [3]. In this process are provided:

- Automated adjustment and ensuring the adequacy of the built geological and technological model to the actual indicators of the field;

- Automated calculation of the material balance for wells and management of well pad modes, fields and the field as a whole;

- Accounting of resources, planning of works, registration of reporting forms taking into account also target indicators of the previously adopted business model and adjustment;

- Optimization of load distribution among wells, aggregates and plants, planning of repair, maintenance and intensification of the field production;

- Adaptation of the field Regime Management System (RMS), compliance with the risk model and modes;

- Technological and environmental safety of the field;

- Real-time adaptation of the field regime management system (RMS), compliance with the risk model and regimes.

The basic trend for digital technologies is a repetitive corrective control cycle: Measurement - Correction - Control - Forecast - Impact-Control. At the same time, it is important to provide with technical means the possibility of operational measurements, analysis and operational regulation between fields and selections along well clusters and individual wells.

It can be expected that more than $10 \%$ of the total number of oil and gas fields will be covered by digital technologies of oil and gas production by 2023-2025. The world's best practices have shown the effectiveness of the principles of «digital» field in oil and gas facilities, 
which provides in the process of operation an increase in recoverable reserves of gas and oil production of at least $10 \%$, reducing the downtime of wells about $50 \%$ of the initial level and reducing operating costs of about $10-25 \%$.

The implementation of digital technologies allows: rational use of reservoir pressure; optimize the operation of equipment and well operation; reduce costs and improve technological and environmental safety.

Статья написана в рамках выполнения государственного задания (тема «Фундаментальный базис инноващионных технологий нефтяной $u$ газовой промышленности (фундаментальные, поисковые и прикладные исследования)», № ААААA19-119013190038-2).

\section{References}

1. Stolyarov V.E., Basnieva I.K., Eremin N.A., Eremina I.A., Kraus Z.T., Sardanashvili O.N., Yufin P.A. Digitalization of gas production technologies // Actual Problems of Oil and Gas. 2018. Iss. 2(21). https://doi.org/10.29222/ipng.2078-5712.2018-21.art10 (In Russ.).

2. Stolyarov V.E., Eremin N.A. The optimization of the gas production processes by the application of the digital technologies // Geology, Geophysics and Development of Oil and Gas Fields. 2018. No. 6. P. 54-61. https://doi.org/10.30713/2413-5011-2018-6-54-61 (In Russ.).

3. Dmitrievsky A.N., Martynov V.G., Abukova L.A., Eremin N.A. Questions digitalization and intellectualization of oil and gas fields // Fundamental basis of innovative technologies of oil and gas field prospecting, exploration and development and priority directions of Russian fuel and energy resource base development: Collected papers. Moscow: Gubkin Russian State University of Oil and Gas, 2016. P. 29-37. (In Russ.). 


\title{
К вопросу применения беспроводных решений и технологий в цифровой нефтегазовой добыче
}

\author{
А.Н. Дмитриевский ${ }^{1}$, Н.А. Еремин ${ }^{1 *}$, В.Е. Столяров ${ }^{1,2}$ \\ 1 - Институт проблем нефти и газ РАН, г. Москва; \\ $2-$ - ПАО «Газпром», г. Москва \\ E-mail: *ermn@mail.ru
}

\begin{abstract}
Аннотация. Применению удаленного управления промысловыми объектами $и$ скважинами в нефтегазодобыче исторически предшествовало развитие автоматических и автоматизированных технологий бурения, создание интегрированных моделей эффективной добычи, обустройство подземной и надземной части промыслов на базе энергозависимых решений. Наличие при этом прямой связи между автоматизированными (цифровыми) скважинами и цифровыми (интеллектуальными) месторождениями не вызывает сомнения. Практика показала, что до середины 60-х годов автоматические устройства на отечественных месторождениях практически не применялись и только в последнее десятилетие этот процесс получил ускорение в связи с большим количеством месторождений, находящихся на стадии «падающая добыча».
\end{abstract}

Ключевые слова: цифровая нефтегазовая добыча, беспроводные решения, беспроводные технологии, нефть, газ, добыча, энергоэффективность, механизированная добыча, поддержание пластового давления, схема принятия решений.

Для цитирования: Дмитриевский А.Н., Еремин Н.А., Столяров В.Е. К вопросу применения беспроводных решений и технологий в цифровой нефтегазовой добыче // Актуальные проблемы нефти и газа. 2019. Вып. 2(25). https://doi.org/10.29222/ipng.2078-5712.2019-25.art11

\section{Литература}

1. Столяров В.Е., Басниева И.К., Еремин Н.А., Еремина И.А., Краус 3.Т., Сарданашвили О.Н., Юфин П.А. Цифровизация технологий добычи газа // Актуальные проблемы нефти и газа. 2018. Вып. 2(21). https://doi.org/10.29222/ipng.2078-5712.2018-21.art10

2. Столяров B.E., Еремин Н.A. Оптимизация процессов добычи газа при применении цифровых технологий // Геология, геофизика и разработка нефтяных и газовых месторождений. 2018. № 6. С. 54-61. https://doi.org/10.30713/2413-5011-2018-6-54-61

3. Дмитриевский А.Н., Мартынов В.Г., Абукова Л.А., Еремин Н.А. Вопросы цифровизации и интеллектуализация нефтегазовой отрасли // Фундаментальный базис инновационных технологий поисков, разведки и разработки месторождений нефти и газа и приоритетные направления развития ресурсной базы ТЭК России: Сб. науч. ст. М.: Издво РГУ нефти и газа им. И.М. Губкина. 2016. С. 29-37. 